\title{
PENERAPAN PRINSIP RESTORATIVE JUSTICE DALAM SISTEM PERADILAN PIDANA DI INDONESIA
}

\author{
Hanafi Arief; Ningrum Ambarsari \\ Fakultas Hukum Universitas Islam Kalimantan MAB \\ Jl. Adhyaksa No.2 Kayutangi, Banjarmasin, Kalimantan Selatan \\ Email: hanafi_arief@yahoo.com; ningrum74fhuniska@gmail.com
}

\begin{abstract}
In the practice of criminal law enforcement often heard the term Restorative Justice, or the restoration of Justice in the Indonesia language translation called restorative justice terms. restorative justice or Restorative Justice contains sense: "a rapprochement and the redemption of the errors committed by the perpetrator wanted criminal (his family) against the victims of such criminal acts (his family) (an effort Peace) out of court with the purpose and goal of keeping legal issues that arise due to the occurrence of the Criminal deeds can be completed with either with someone else's approval and an agreement among the parties. Short term goals are expected of this research is to find the root of the problem the law against legal setting Restorative Justice. A long-term goal of this research can be a proper framework and effectively in the implementation of Restorative Justice in the criminal justice system in Indonesia. This research uses the juridical normative research methods. This normative legal research done on qualitative diskriptif, i.e. the material or materials are collected, the legal dipilah-pilah for further studied and analyzed, so that the charge can be found in standard sync, the eligibility norms, and the filing of new normative ideas.
\end{abstract}

Keyword: Law Enforcement, Application Of Restorative Justice, Criminal Justice.

\begin{abstract}
Abstrak
Praktek penegakan hukum pidana sering kali mendengar istilah Restorative Justice, atau Restorasi Justice yang dalam terjemahan bahasa Indonesia disebut dengan istilah keadilan restorative. keadilan restoratif atau Restorative Justice mengandung pengertian yaitu: "suatu pemulihan hubungan dan penebusan kesalahan yang ingin dilakukan oleh pelaku tindak pidana (keluarganya) terhadap korban tindak pidana tersebut (keluarganya) (upaya perdamaian) di luar pengadilan dengan maksud dan tujuan agar permasalahan hukum yang timbul akibat terjadinya perbuatan pidana tersebut dapat diselesaikan dengan baik dengan tercapainya persetujuan dan kesepakatan diantara para pihak. Tujuan jangka pendek yang diharapkan dari penelitian ini adalah mencari akar permasalahan hukum terhadap pengaturan hukum Restorative Justice. Tujuan jangka panjang dari penelitian ini dapat menjadi kerangka kerja yang tepat dan efektif dalam pelaksanaan Restorative Justice dalam sistem peradilan pidana di Indonesia. Penelitian ini menggunakan metode penelitian yuridis normatif. penelitian hukum normatif ini dilakukan secara diskriptif kualitatif, yaitu materi atau bahanbahan hukum tersebut dikumpulkan, dipilah-pilah untuk selanjutnya dipelajari dan dianalisis muatannya, sehingga dapat diketahui taraf sinkronisasinya, kelayakan norma, dan pengajuan gagasan-gagasan normatif baru.
\end{abstract}

Kata Kunci: Penegakan Hukum, Keadilan Restorative, Peradilan Pidana. 


\section{LATAR BELAKANG MASALAH}

Di dalam praktek penegakan hukum pidana sering kali mendengar istilah Restorative Justice, atau Restorasi Justice yang dalam terjemahan bahasa Indonesia disebut dengan istilah keadilan restorative. Keadilan restoratif atau Restorative Justice mengandung pengertian yaitu: "suatu pemulihan hubungan dan penebusan kesalahan yang ingin dilakukan oleh pelaku tindak pidana (keluarganya) terhadap korban tindak pidana tersebut (keluarganya) (upaya perdamaian) di luar pengadilan dengan maksud dan tujuan agar permasalahan hukum yang timbul akibat terjadinya perbuatan pidana tersebut dapat diselesaikan dengan baik dengan tercapainya persetujuan dan kesepakatan diantara para pihak".

Keadilan yang selama ini berlangsung dalam sistem peradilan pidana di Indonesia adalah keadilan retributive. Sedangkan yang diharapkan adalah keadilan restorative, yaitu keadilan ini adalah suatu proses dimana semua pihak yang terlibat dalam suatu tindak pidana tertentu bersama-sama memecahkan masalah bagaimana menangani akibatnya dimasa yang akan datang. Keadilan Restoratif adalah model penyelesaian perkara pidana yang mengedepankan pemulihan terhadap korban, pelaku, dan masyarakat. Prinsip utama Restorative Justice adalah adanya partisipasi korban dan pelaku, partisipasi warga sebagai fasilitator dalam penyelesaian kasus, sehingga ada jaminan anak atau pelaku tidak lagi mengganggu harmoni yang sudah tercipta di masyarakat. ${ }^{1}$

Tindak pidana menurut kaca mata keadilan Restoratif, adalah suatu pelanggaran terhadap manusia dan relasi antar manusia. Keadilan restoratif, dapat dilaksanakan melalui: Mediasi korban dengan pelanggar; Musyawarah kelompok keluarga; pelayanan di masyarakat yang bersifat pemulihan baik bagi korban maupun pelaku.

Penerapan prinsip keadilan restoratif itu tergantung pada sistem hukum apa yang dianut oleh suatu negara. Jika dalam sistem hukum itu tidak menghendaki, maka tidak bisa dipaksakan penerapan Restorative Justice tersebut. Sehingga dapat disimpulkan bahwa prinsip Restorative Justice merupakan pilihan dalam mendesain sistem hukum suatu negara. Walaupun suatu negara tidak menganutnya, akan tetapi tidak menutup kemungkinan untuk diterapkan prinsip keadilan restoratif tersebut guna

1 Apong Herlina dkk, Perlindungan Terhadap Anak Yang Berhadapan Dengan Hukum, PT. Raja Grafindo Persada, Jakarta, 2004. 
memberikan keadilan, kepastian dan kemanfaatan hukum

Penegakan hukum di Indonesia kini masih meninggalkan berbagai persoalan yang harus diselesaikan, terutama kasus-kasus pidana yang melibatkan satu pihak dengan pihak lainnya di masyarakat. Rasa keadilan yang diharapkan dari penegakan hukum belum bisa dinikmati masyarakat di negara ini. Apalagi seperti diketahui sistem peradilan pidana di Indonesia tidak banyak mengatur mengenai korban. Dengan demikian kadangkala keberadaan korban cenderung diindahkan atau "terlupakan", mengingat sistem ini lebih fokus kepada pelaku kejahatan. Perlindungan hak-hak korban pada hakikatnya merupakan bagian dari perlindungan hak asasi manusia. Korban membutuhkan perlindungan untuk menjamin hak-haknya terpenuhi. Karena selama ini di dalam sistem peradilan pidana di Indonesia hakhak korban kurang terlindungi dibanding hak-hak tersangka. Dalam permasalahan ini, Restorative Justice bisa menjadi solusi bagi keadaan atau kondisi tersebut.

\section{RUMUSAN MASALAH}

Rumusan masalah dalam penelitian ini adalah:
1. Bagaimana Kedudukan Hukum (Legal Standing) Terhadap Penerapan Restorative Justice?

2. Bagaimana Penerapan Restorative Justice Dalam Sistem Peradilan Pidana di Indonesia?

\section{METODE PENELITIAN}

Metode penelitian yang digunakan dalam penelitian ini adalah yuridis normatif, yaitu penelitian yang dalam pengkajiannya dengan mengacu dan mendasarkan pada norma-norma dan kaidah-kaidah hukum, peraturan perundang-undangan yang berlaku, teoriteori dan doktrin hukum, yurisprudensi, dan bahan-bahan kepustakaan lainnya yang relevan dengan topik penelitian. Pengumpulan bahan hukum dilakukan dengan studi pustaka yakni melalui pengakajian terhadap peraturan-peraturan yang mengatur tentang restorative justice serta berbagai pustaka yang relevan dengan objek penelitian.

Pendekatan yang digunakan dalam penelitian ini adalah pendekatan yuridis, yakni menganalisis permasalahan tentang pelaksanaan prinsip restorative justice dalam sistem peradilan pidana di Indonesia. 


\section{PEMBAHASAN}

\section{Kedudukan Hukum (Legal Standing)}

Terhadap Penerapan Restorative Justice

Mengenai penegakan hukum di

Indonesia, tidak akan bisa terlepas dari Undang-Undang Nomor 8 Tahun 1981

Tentang Hukum Acara Pidana karena berdasarkan kata-kata nya saja, istilah tersebut mengacu pada pelaksanaan hukum formil. Bisa dibilang yang dimaksud dengan penegakan hukum (law enforcement), bentuk kongkritisasinya adalah merupakan penjatuhan pidana atau sanksi. Berkaitan dengan hal tersebut, menurut Sauer ada tiga pengertian dasar dalam hukum pidana, yaitu sifat melawan hukum, kesalahan dan pidana. ${ }^{2}$ Dan selain identik dengan hukum formil, penegakan juga harus didasarkan atas peraturan yang dibuatnya. Berkenaan dengan pembuatan peraturan tersebut, ada satu aliran dan satu teori, yaitu Aliran Utilitarianisme dengan tokohnya Jeremy Bentham, yang pada dasanya menyatakan bahwa setiap peraturan yang dibuat harus mempunyai nilai guna untuk masyarakat.

Dikatakan dalam uraian menurut Bagir Manan, bahwa penegakan hukum indonesia bisa dikatakan "communis

2 Dwidja Priyatno, Pemidanaan untuk Anak dalam Konsep Rancangan KUHP (dalam Kerangka Restorative Justice), Lembaga Advokasi Hak Anak (LAHA), Edisi VIII/Volume III, Bandung, 2007, hlm. 9. opinio doctorum", yang artinya bahwa penegakan hukum yang sekarang dianggap telah gagal dalam mencapaui tujuan yang diisyaratkan oleh UndangUndang. ${ }^{3}$ Oleh karena itu, diperkenankanlah sebuah alternatif penegakan hukum, yaitu Restorative Justice System, dimana pendekatan yang digunakan adalah pendekatan sosiokultural dan bukan pendekatan normatif.

Di banyak negara, ketidakpuasan dan frustrasi dengan sistem peradilan formal atau melahirkan kembali kepentingan dalam melestarikan dan memperkuat hukum adat dan praktek peradilan tradisional telah menyebabkan panggilan untuk respon alternatif untuk kejahatan dan gangguan sosial. Banyak alternatif ini memberikan pihak yang terlibat, dan sering juga masyarakat sekitar, kesempatan untuk berpartisipasi dalam menyelesaikan konflik dan mengatasi konsekuensinya. Program keadilan restoratif didasarkan pada keyakinan bahwa pihak yang terlibat konflik harus secara aktif terlibat dalam menyelesaikan dan mengurangi konsekuensi negatif. Mereka juga didasarkan, dalam beberapa kasus, pada kemauan untuk kembali ke bangunan

\footnotetext{
3 Rudi Rizky (ed), Refleksi Dinamika Hukum (Rangkaian Pemikiran dalam Dekade Terakhir), Perum Percetakan Negara Indonesia, Jakarta, 2008, hlm. 4.
} 
pengambilan keputusan dan masyarakat setempat. Pendekatan-pendekatan ini juga dilihat sebagai sarana untuk mendorong ekspresi damai konflik, untuk mempromosikan toleransi dan inklusivitas, membangun penghargaan atas keragaman dan mempromosikan praktek masyarakat yang bertanggung jawab. ${ }^{4}$

\section{Restorative Justice (Keadilan} restoratif) sebagai perkembangan penting dalam pemikiran manusia didasarkan pada tradisi keadilan dari Arab kuno, Yunani, Romawi dan peradaban yang diterima pendekatan restoratif bahkan kasus pembunuhan, pendekatan restoratif dari majelis umum (Moots) dari Jermanik masyarakat yang menyapu seluruh Eropa setelah jatuhnya Roma, Hindu India sebagai kuno sebagai Weda Peradaban untuk siapa "dia yang menebus diampuni", dan Budha kuno, Tao, dan tradisi Konfusianisme yang dilihatnya dicampur dengan pengaruh Barat hari ini di Asia Utara. ${ }^{5}$

Bentuk baru dan mapan dari restoratif keadilan masyarakat menawarkan beberapa cara menyambut menyelesaikan konflik. Mereka

4 UNODC, Handbook on Restorative Justice Programmes. Criminal Justice Handbook Series, UN New York, Vienna, 2006, hlm. 5

${ }^{5}$ John Braithwaite, Restorative Justice \& Responsive Regulation, Oxford University Press, England, 2002, hlm. 3. melibatkan individu yang tidak terlepas dari insiden itu, tetapi secara langsung terlibat atau terpengaruh olehnya. Partisipasi masyarakat dalam proses tidak lagi abstrak, melainkan sangat langsung dan konkret. Proses ini sangat disesuaikan dengan situasi di mana pihak berpartisipasi secara sukarela dan masingmasing memiliki kapasitas untuk terlibat penuh dan aman dalam proses dialog dan negosiasi. John Braithwaite menjelaskan bahwa wacana restoratif justice berfokus pada program keadilan restoratif dalam masalah pidana, tetapi perlu dicatat bahwa proses restoratif yang digunakan untuk mengatasi dan menyelesaikan konflik di berbagai konteks dan pengaturan lainnya, termasuk sekolah dan tempat kerja. ${ }^{6}$

Restorative Justice (Keadilan Restoratif) atau dikenal dengan istlah "reparative justice" adalah suatu pendekatan keadilan yang memfokuskan kepada kebutuhan dari pada para korban, pelaku kejahatan, dan juga melibatkan peran serta masyarakat, dan tidak sematamata memenuhi ketentuan hukum atau semata-mata penjatuhan pidana. Dalam hal ini korban juga dilibatkan di dalam proses, sementara pelaku kejahatan juga didorong untuk mempertanggungjawabkan atas tindakannya, yaitu dengan memperbaiki 
kesalahan-kesalahan yang telah mereka perbuat dengan meminta maaf, mengembalikan uang telah dicuri, atau dengan melakukan pelayanan masyarakat.

Restorative Justice bertujuan untuk memberdayakan para korban, pelaku, keluarga, dan masyarakat untuk memperbaiki suatu perbuatan melawan hukum dengan menggunakan kesadaran dan keinsyafan sebagai landasan untuk memperbaiki kehidupan bermasyarakat menjelaskan bahwa konsep Restorative Justice pada dasarnya sederhana. ${ }^{7}$ Restorative Justice merupakan teori keadilan yang menekan kan pada pemulihan kerugian yang disebabkan oleh perbuatan pidana.

Pendekatan Restorative justice memfokuskan kepada kebutuhan baik korban maupun pelaku kejahatan. Di samping itu, pendekatan Restorative Justice (Keadilan Restoratif) membantu para pelaku kejahatan untuk menghindari kejahatan lainnya pada masa yang akan datang. Hal ini didasarkan pada sebuah teori keadilan yang menganggap kejahatan dan pelanggaran, pada prinsipnya adalah pelanggaran terhadap individu atau masyarakat dan bukan kepada negara. Restorative Justice (Keadilan Restoratif)

${ }^{7}$ Nikmah Rosidah, Budaya Hukum Hakim Anak Di Indonesia, Pustaka Magister; Semarang, 2014, hlm. 103. menumbuhkan dialog

antara korban

dan pelaku akan menunjukkan tingkat tertinggi kepuasan korban

dan

akuntabilitas pelaku.

Konsep Restorative Justice (Keadilan Restoratif) pada dasarnya sederhana. Ukuran keadilan tidak lagi berdasarkan pembalasan setimpal dari korban kepada pelaku (baik secara fisik, psikis atau hukuman); namun perbuatan yang menyakitkan itu disembuhkan dengan memberikan dukungan kepada korban dan mensyaratkan pelaku untuk bertanggungjawab, dengan bantuan keluarga dan masyarakat bila diperlukan.

Dalam ke-Indonesia-an, maka diartikan bahwa Restorative Justice sendiri berarti penyelesaian secara adil yang melibatkan pelaku, korban, keluarga dan pihak lain yang terkait dalam suatu tindak pidana dan secara bersama mencari penyelesaian terhadap tindak pidana dan implikasinya dengan menekankan pemulihan kembali pada keadaan semula.

Untuk mewujudkan keadilan bagi korban dan pelaku, adalah baik ketika para penegak hukum berpikir dan bertindak secara progresif yaitu tidak menerapkan peraturan secara tekstual tetapi perlu menerobos aturan (rule breaking) karena pada akhirnya hukum itu bukan teks demi tercapainya keadilan yang diidamkan oleh masyarakat. 
Hukum yang progresif berangkat dari asumsi dasar bahwa hukum adalah untuk manusia, bukan sebaliknya. Hukum bukan sebagai institusi yang bersifat mutlak dan final, melainkan sebagai institusi bermoral, bernurani dan karena itu sangat ditentukan oleh kemampuannya untuk mengabdi kepada manusia. Hukum adalah suatu institusi yang bertujuan untuk mengantarkan manusia kepada kehidupan yang adil, sejahtera dan membuat manusia bahagia. Kemanusiaan dan keadilan menjadi tujuan dari segalanya dalam kita berkehidupan hukum. Maka kalimat "hukum untuk manusia" bermakna juga "hukum untuk keadilan”. Ini berarti, bahwa kemanusiaan dan keadilan ada di atas hukum. Intinya adalah penekanan pada penegakan hukum berkeadilan yang di Indonesia yaitu terciptanya kesejahteraan masyarakat atau yang sering disebut dengan "masyarakat yang adil dan makmur". 8

Sedikit mengambil posisi yang berbeda, Bagir Manan menjelaskan bahwa restorative justice adalah konsep pemidanaan, tetapi sebagai konsep pemidanaan tidak hanya terbatas pada ketentuan hukum pidana (formal dan materil). ${ }^{9}$ Namun, walaupun Bagir Manan mendefinisikan restoratif justice sebagai

\footnotetext{
${ }^{8}$ Rudi Rizky (ed), Loc.cit.

${ }^{9}$ Ibid
}

konsep pemidanaan, Beliau tetap sejalan dengan pemikiran bahwa konsep pemidanaan tersebut haruslah mengedepankan keadilan, yang ditegaskan dengan istilah keadilan terpadu, yaitu keadilan bagi pelaku, keadilan bagi korban dan keadilan bagi masyarakat.

"Restorative justice" sebagai salah usaha untuk mencari penyelesaian konflik secara damai di luar pengadilan masih sulit diterapkan. Di Indonesia banyak hukum adat yang bisa menjadi restorative justice, namun keberadaannya tidak diakui negara atau tidak dikodifikasikan dalam hukum nasional. Hukum adat bisa menyelesaikan konflik yang muncul di masyarakat dan memberikan kepuasan pada pihak yang berkonflik. Munculnya ide restorative justice sebagai kritik atas penerapan sistem peradilan pidana dengan pemenjaraan yang dianggap tidak efektif menyelesaikan konflik sosial. Penyebabnya, pihak yang terlibat dalam konflik tersebut tidak dilibatkan dalam penyelesaian konflik. Korban tetap saja menjadi korban, pelaku yang dipenjara juga memunculkan persoalan baru bagi keluarga dan sebagainya. ${ }^{10}$

10 Setyo Utomo, Sistem Pemidanaan Dalam Hukum Pidana Yang Berbasis Restorative Justice, Mimbar Justitia Fakultas Hukum Universitas Suryakancana, Volume 5 Nomor 01, hlm. 86. 


\section{Restorative justice didasarkan} pada suatu, pemahaman yang logis terhadap kesalahan. Meskipun akan dinyatakan secara berbeda dalam budaya yang berbeda, pendekatan ini mungkin umum bagi sebagian besar masyarakat tradisional. Menurut Prinsip-Prinsip Dasar, sebuah "hasil restoratif" adalah kesepakatan yang dicapai sebagai hasil dari suatu proses restoratif. Perjanjian tersebut mungkin termasuk rujukan ke program-program seperti reparasi, restitusi, dan masyarakat jasa, "ditujukan untuk memenuhi kebutuhan individu dan kolektif dan tanggung jawab berbagai pihak dan mencapai reintegrasi korban dan pelaku". Hal ini juga dapat dikombinasikan dengan langkah-langkah lain dalam kasus yang melibatkan pelanggaran serius. ${ }^{11}$

Menurut Setyo Utomo, bahwa terdapat ciri lain yang menonjol dari restorative justice, dimana kejahatan ditempatkan sebagai gejala yang menjadi bagian tindakan sosial dan bukan sekadar pelanggaran hukum pidana. Kejahatan dipandang sebagai tindakan yang merugikan orang dan merusak hubungan sosial. Berbeda dengan hukum pidana yang telah menarik kejahatan sebagai masalah negara. Hanya negara yang berhak menghukum, meskipun sebenarnya

\footnotetext{
${ }^{11}$ UNODC, Op.cit, hlm. 7.
}

komunitas adat bisa saja memberikan sanksi. $^{12}$

Dalam perkembangan wacana teoritik maupun perkembangan pembaharuan hukum pidana di berbagai negara, ada kecenderungan kuat untuk menggunakan mediasi pidana/penal (penal mediation) sebagai salah satu alternatif penyelesaian masalah di bidang hukum pidana. Menurut Detlev Frehsee ${ }^{13}$, meningkatnya penggunaan restitusi dalam proses pidana menunjukkan, bahwa perbedaan antara hukum pidana dan perdata tidak begitu besar dan perbedaan itu menjadi tidak berfungsi.

Selain itu, sebagai perbandingan maka penal mediation ditingkat internasional telah lama dikenal. Dalam beberapa konferensi misalnya Konggres PBB ke-9 tahun 1995 khususnya yang berkorelasi dengan manajemen peradilan pidana (dokumen A/CONF 169/6) disebutkan perlunya semua negara mempertimbangkan "privatizing some law enforcement and justice functions" dan Alternative Dispute Resolution/ADR) berupa mediasi, konsiliasi, restitusi dan kompensasi dalam sistem peradilan pidana.

\footnotetext{
${ }^{12}$ Setyo Utomo, Loc.cit.

13 Barda Nawawi Arief, Mediasi Penal Penyelesaian Perkara Diluar Pengadilan, Pustaka Magister, Semarang, 2008, hlm. 4-5.
} 
Kemudian dalam Konferensi Internasional Pembaharuan Hukum Pidana (International Penal Reform Conference) tahun 1999 dikemukakan bahwa salah satu unsur kunci dari agenda baru pembaharuan hukum pidana (the key elements of a new agenda for penal reform) adalah perlunya memperkaya sistem peradilan formal dengan sistem atau mekanisme informal dengan standarstandar hak asasi manusia (the need to enrich the formal judicial system with informal, locally based, dispute resolution mechanisms which meet human rights standards) yang mengindentifikasikan sembilan strategi pengembangan dalam melakukan pembaharuan hukum pidana melalui pengembangan restorative justice, alternative dispute resolution, informal justice, alternatives to custody, alternative ways of dealing with juveniles, dealing with violent crime, reducing the prison population, the proper management of prisonsdan the role of civil in penal reform. ${ }^{14}$

${ }^{14}$ Lilik Mulyadi, "Penyelesaian Perkara Di Luar Pengadilan Melalui Dimensi Mediasi Penal (Penal Mediation) Dalam Sistem Peradilan Pidana. Pengkajian Asas, Norma, Teori dan Praktek", Makalah ini dipresentasikan dalam rangka Penelitian untuk wilayah Pengadilan Tinggi Palangkaraya, Mataram, Jambi dan Semarang diselenggarakan Badan Penelitian dan Pengembangan dan Pendidikan dan Pelatihan Hukum dan Peradilan Mahkamah Agung RI (Badan Litbang Diklat Kumdil MARI) pada bulan April-Mei Tahun 2011.
Munculnya konsep restorative

justice bukan berarti meniadakan pidana penjara, dalam perkara-perkara tertentu yang menimbulkan kerugian secara massal dan berkaitan dengan berharga nyawa seseorang, maka pidana penjara masih dapat dipergunakan. Konsep restorative justice merupakan suatu konsep yang mampu berfungsi sebagai akselerator dari Asas peradilan sederhana, cepat dan biaya ringan, sehingga lebih menjamin terpenuhinya kepastian hukum dan keadilan masyarakat.

Di dalam praktek sistem peradilan di Indonesia terdapat perkembangan mengenai konsep tujuan pemidanaan, mulai retribution yang merupakan bentuk pembalasan secara absoluth terhadap seseorang yang telah melakukan kejahatan, tanpa harus melihat dampak dan manfaat lebih jauh. Kemudian ada konsep restraint yang bertujuan menjauhkan (mengasingkan) pelaku kejahatan dari kehidupan masyarakat, agar masyarakat aman, tenang, terhindar dari keresahan dari ulah kejahatan serupa. Ada juga konsep deterrence individual dan general deterrence, yang dimaksudkan agar hukuman membuat si pelaku secara individual merasa jera (individual detterance) atau sekaligus ditujukan supaya dijadikan Sebagai contoh 
masyarakat agar tidak melakukan kejahatan serupa (general deterrence) Perkembangan selanjutnya adalah konsep reformation atau rehabilitation, suatu bentuk penghukuman yang dimaksudkan untuk memperbaiki atau merehabilitasi si pelaku kejahatan agar pulih menjadi orang baik yang dapat diterima kembali di lingkungan masyarakatnya.

Konsep-konsep pemidanaan tersebut terus berkembang dalam teoriteori keadilan dari yang tradisional seperti retributive justice, rehabilitative justice, sampai ke teori yang lebih modern seperti alternative justice, transitional justice dan belakangan berkembang teori restorative justice. Restorative justice oleh sebagian pakar hukum pidana, psikolog dan pakar perilaku anak dipandang tepat dan baik dalam sistem peradilan pidana guna penyelesaian permasalahan anak yang berkonflik dengan hukum, baik itu dari sisi pelaku, korban, keluarga pelaku/korban, maupun stakeholder lainnya demi diperolehnya rasa keadilan yang ada di tengah masyarakat. Restorative justice merupakan bentuk penyelesaian konflik yang tidak hanya mengadili dan menghukum pelaku dengan suatu pembalasan, tetapi lebih mengedepankan pada terpulihkannya keadaan semula atau kondisi normal dari korban, pelaku, keluarga pelaku/korban ataupun stakeholder lainnya yang berkepentingan. Keadilan ini di satu sisi dapat menjelaskan bahwa apa yang dilakukan oleh pelaku tidak dapat dibenarkan secara hukum, namun di sisi lain juga melindungi dan menghormati hak-hak individu yang lebih mendasar.

Menurut pandangan konsep restorative justice penanganan kejahatan yang terjadi bukan hanya menjadi tanggung jawab negara akan tetapi juga merupakan tanggung jawab masyarakat. Oleh karena itu konsep restorative justice di bangun berdasarkan pengertian bahwa kejahatan yang telah menimbulkan kerugian harus dipulihkan kembali baik kerugian yang di derita oleh korban maupun kerugian maupun yang di tanggung oleh masyarakat. Keterlibatan anggota masyarakat sangat dibutuhkan untuk membantu memperbaiki kesalahan dan penyimpangan yang terjadi di sekitar lingkungan masyarakat yang bersangkutan. Pemberian penghargaan dan penghormatan pada korban dengan mewajibkan pihak pelaku melakukan pemulihan kembali atau akibat tindak pidana yang telah dilakukannya. Pemulihan yang dilakukan oleh pelaku bisa berupa ganti rugi, pekerjaan sosial atau melakukan sesuatu perbaikan atau kegiatan tertentu sesuai dengan keputusan bersama yang telah disepakati semua 
pihak dalam pertemuan yang dilakukan. Pergeseran pemikiran dari model penghukuman tradisional adalah dengan adanya model penghukuman yang memberikan keadilan, terutama keadilan yang diarahkan pada keadilan masyarakat. Hal ini merupakan suatu titik awal atau dasar lahirnya restorative justice di negara manapun. Adanya pergeseran pemikiran tersebut memperlihatkan bahwa dalam sistem peradilan pidana anak telah terjadi suatu upaya untuk memberikan perhatian dan pemahaman terhadap penyelesaian suatu kasus tindak pidana yang dilakukan dengan tujuan tercapainya keadilan untuk semua pihak yang terkait dalam tindak pidana.

Adapun kedudukan hukum Restorative Justice terdapat pada Pasal 24 ayat (1) Kovenan:

Hak-Hak Sipil dan Politik menentukan bahwa setiap anak berhak untuk mendapatkan hak atas langkahlangkah perrlindungan, karena statusnya sebagai anak di bawah umur seharusnya dapat dijadikan sebagai landasan hukum bagi Hakim untuk menghentikan perkara anak. Putusan demikian sah diberikan karena Hakim diberikan kebebasan dalam Pasal 28 ayat (1) Undang-Undang Nomor 4 Tahun 2004 untuk menggali, mengikuti dan memahami nilai-nilai hukum dan rasa keadilan yang hidup dalam masyarakat.
Kedudukan keadilan restoratif pada sistem peradilan pidana terbagi menjadi dua yaitu: di luar sistem peradilan pidana $^{15}$ dan di dalam sistem peradilan pidana. Kenyataan menunjukkan masyarakat sebagian besar masih bersandar pada hukum negara dan prosedur hukum yang ada. Selain itu, para pembuat kebijakan juga masih percaya dan bergantung kepada sistem peradilan pidana yang sudah berjalan. Dalam hal ini, legislative maupun eksekutif memandang bahwa penggunaan pendekatan keadilan restoratif hanya merupakan alternatif model penyelesaian perkara pidana yang ditawarkan dalam sistem hukum yang berbeda dengan hukum negara yang berlaku. $^{16}$

Kedudukan restorative justice $\mathrm{di}$ Indonesia diatur secara tegas dalam gamblang dalam berbagai peraturan perundang-undangan misalnya UndangUndang Dasar Republik Indonesia Tahun 1945; Undang-Undang Nomor 48 Tahun 2009 Tentang Kekuasaan Kehakiman, Undang-Undang Nomor 14 Tahun 1985 sebagaimana telah diubah oleh UndangUndang Nomor 5 Tahun 2004 sebagaimana telah diubah terakhir dengan Undang-Undang Nomor 3 Tahun 2009

\footnotetext{
${ }^{15}$ Eva Achjani Zulfa. Keadilan Restoratif, Badan Penerbit FH UI, Jakarta, 2009, hlm.17.

${ }^{16}$ Ibid.
} 
Tentang Mahkamah Agung. Dengan demikian, mengingat bahwa Mahkamah Agung (MA) merupakan lembaga negara yang melaksanakan kekuasaan kehakiman dan sebagai puncak peradilan maka sudah seyogianya apabila Mahkamah Agung (MA) mengadopsi atau menganut dan menerapkan pendekatan atau konsep keadilan restoratif (restorative justice).

Selain itu, Undang-Undang Kekuasaan Kehakiman yaitu UndangUndang Republik Indonesia Nomor 48 Tahun 2009 Tentang Kekuasaan Kehakiman tepatnya pada Pasal 5 dengan tegas menyebutkan bahwa hakim wajib menggali nilai-nilai yang hidup dalam masyarakat (the living law atau local wisdom). Dengan demikian, pada hakikatnya hakim harus atau wajib menerapkan pendekatan atau konsep keadilan restoratif (restorative justice) dalam menyelesaikan perkara karena pendekatan atau konsep keadilan restoratif (restorative justice) sesuai dengan jiwa bangsa Indonesia yakni Pancasila, sesuai dengan nilai-nilai hukum adat dan sesuai pula dengan nilai-nilai agama.

Perlu pula dikemukakan bahwa konsep keadilan restoratif (restorative justice) tidak hanya dapat diterapkan kepada Mahkamah Agung (MA). Dalam proses peradilan pidana pada umumnya dan proses peradilan pidana di Indonesia pada khususnya, terdapat beberapa tahapan atau proses yang harus dilalui bagi para pencari keadilan baik di tingkat penyelidikan, penyidikan,penuntutan, pemeriksaan di pengadilan hingga tahap penjatuhan putusan hakim.Bahkan pada tahapan dimana para pencari keadilan melakukan upaya hukum (baik upaya hukum biasa maupun upaya hukum luar biasa). Dengan demikian, penulis menilai bahwa sudah seyogianya pengadopsian dan penerapan konsep keadilan restoratif (restorative justice) dilakukan diberbagai tingkatan atau proses peradilan sebagaimana dikemukakan diatas.

\section{Penerapan Restorative Justice Dalam} Sistem Peradilan Pidana di Indonesia

Dewasa ini, apabila terjadi suatu tindak pidana, masyarakat cenderung menggunakan jalur pengadilan yang secara konseptual dan teoritis akanmenciptakan keadilan, namun dalam kenyataannya hal ini merupakan hal yang tidak mudah untuk dicapai. Perlu disadari bahwa hasil yang akan dicapai dari proses penyelesaian perkara dengan jalur peradilan bersifat win lose solution, dengan sifat yang demikian, akan terdapat pihak yang menang dan terdapat pula pihak yang kalah. Dengan kenyataan seperti ini, penyelesaian suatu perkara melalui jalur peradilan tradisional pada 
umumnya kerap menimbulkan satu rasa "tidak enak", menyimpan dendam, merasa tidak puas, merasa tidak adil bahkan lebih parah berniat ingin membalas dendam.

Sistem peradilan pidana (criminal justice system) adalah suatu sistem yang mengatur cara bagaimana suatu perkara pidana yang telah terjadi akan diselesaikan dalam suatu rangkaian kegiatan peradilan dengan tujuan tercapainya keadilan dan memperoleh kepastian hukum. Karena sistem peradilan pidana adalah sebagai suatu sistem, maka antara masing-masing komponen yang terdapat dalam sistem saling terkait satu dengan yang lain, artinya sistem ini tidak pernah berjalan dan sampai pada tujuannya jika salah satu bagian dari sistem itu tidak bekerja.

Muladi dalam bukunya yang berjudul "Kapita Selekta Sistem Peradilan Pidana" mengemukakan bahwa sistem peradilan pidana (criminal justice system) adalah suatu jaringan (network) peradilan yang menggunakan hukum pidana materiil, hukum pidana formil maupun hukum pelaksanaaan pidana.Namun kelembagaan ini harus dilihat dalam konteks sosial. ${ }^{17}$ Sifat yang terlalu formal jika dilandasi hanya untuk kepentingan

17 Muladi, Kapita Selekta Sistem Peradilan Pidana, Badan Penerbit UNDIP, Semarang, 1996, hlm. 2. kepastian hukum saja akan membawa bencana berupa ketidakadilan. ${ }^{18}$

Sistem peradilan pidana (criminal justice system) di Indonesia diatur secara tegas dalam Kitab Undang-Undang Hukum Acara Pidana (KUHAP) atau Undang-Undang No. 8 tahun 1981. Dikatakan demikian karena UndangUndang No. 8 tahun 1981 atau Kitab Undang-Undang Hukum Acara Pidana (KUHAP) sebenarnya identik dengan penegakan hukum pidana yang merupakan suatu sistem kekuasaan atau kewenangankewenangan yang diberikan kepada negara dalam menegakkan hukum pidana yakni kepolisian, kejaksaan, hakim dan lembaga pemasyarakatan. Pengertian sistem peradilan pidana (criminal justice system) disebut juga dengan istilah law enforcement system karena di dalamnya mengandung suatu pemahaman, bahwa pada dasarnya apa yang dilakukan oleh lembaga-lembaga itu merupakan usaha konkrituntuk menegakkan aturan-aturan hukum abstrak. ${ }^{19}$

Terkait dengan integrated criminal justice system atau sistem peradilan pidana terpadu, Muladi dalam bukunya yang berjudul "Kapita Selekta Sistem Peradilan Pidana" menegaskan bahwa

${ }^{18}$ Ibid.

19 Bryan A. Garner, Black's Law Dictionary, Edisi Delapan, West Publishing CO, Amerika Serikat, 2004, hlm. 901. 
makna sistem peradilan pidana terpadu atau integrated criminal justice system merupakan suatu sinkronisasi atau keserampakan dan keselarasan, yang dapat dibedakan dalam beberapa hal berikut ini:: ${ }^{20}$ 1) Sinkronisasi struktural (structural syncronization) adalah keserampakan atau keselarasan dalam rangka hubungan antar lembaga penegak hukum; 2) Sinkronisasi substantial (substansial syncronization) adalah keserampakan atau keselarasan yang bersifat vertikal dan horizontal dalam kaitannya dengan hukum positif; dan 3) Sinkronisasi kultural (cultural syncronization) adalah keselarasan dalam menghayati pandangan-pandangan, sikapsikap dan falsafah yang secara menyeluruh mendasari jalannya sistem peradilan pidana.

Restorative justice dapat dirumuskan sebagai sebuah pemikiran yang merespon pengembangan sistem peradilan pidana dengan menitikberatkan kepada kebutuhan pelibatan masyarakat dan korban yang dirasa tersisihkan dengan mekanisme yang bekerja pada sistem peradilan pidana yang ada pada saat ini. Selain itu, restorative justice dapat dijadikan suatu kerangka berpikir yang dapat digunakan dalam merespon suatu tindak pidana bagi penegak hukum.
Terhadap kasus tindak pidana, maka restorative justice system setidaktidaknya bertujuan untuk memperbaiki /memulihkan (to restore) perbuatan kriminal yang dilakukan pelaku dengan tindakan yang bermanfaat bagi pelaku, korban dan lingkungannya yang melibatkan mereka secara langsung dalam penyelesaian masalah, dan berbeda dengan cara penanganan orang dewasa, yang kemudian akan bermuara pada tujuan dari pidana itu sendiri tujuan pemidanaan bertitik tolak kepada "perlindungan masyarakat" dan "perlindungan/pembinaan individu pelaku tindak pidana".

Keadilan Restorative adalah harmonisasi antar warga masyarakat bukan pada penghukuman. Lima unsur utama keadilan Restorative Justice adalah:

1. Restorative justice adalah satu jenis keadilan yang merupakan konsep hukum proses pidana atau criminal justice sistem yang diakui secara universal dan yang diawali ini semakin banyak digunakan dalam berbagai kasus pidana di negara maju.

2. Restorative justice memandang tindak pidana itu bukan kejahatan terhadap negara/publik melainkan kejahatan terhadap korban. Ini bisa

\footnotetext{
${ }^{20}$ Muladi, Op.Cit., hlm. 1-2.
} 
berbentuk perseorangan atau beberapa orang/kelompok.

3. Restorative justice berfokus pada penderitaan atau kerugian yang diderita oleh korban dan bukan pada pemidanaan terhadap pelaku.

4. Restorative justice dapat berwujud dialog langsung atau tidak langsung dalam wujud mediasi ataupun rekonsiliasi ataupun pengadilan.

5. Restorative justice tidak hanya dalam wujud rekonsiliasi yang bersifat transsisional seperti dalam pemaparan.

Dalam berbagai asas dan model pendekatan restorative justice, proses dialog antara pelaku dan korban merupakan modal dasar dan bagian terpenting dari penerapan keadilan ini. Dialog langsung antara pelaku dan korban menjadikan korban dapat mengungkapkan apa yang dirasakannya, mengemukakan harapan akan terpenuhinya hak-hak dan keinginan-keinginan dari suatu penyelesaian perkara pidana. Melalui dialog juga pelaku diharapkan tergugah hatinya untuk mengoreksi diri, menyadari kesalahannya dan menerima tanggung jawab sebagai konsekuensi dari tindak pidana yang dilakukan dengan penuh kesadaran. Dari proses dialog ini pula masyarakat dapat turut serta berpartisipasi dalam mewujudkan hasil kesepakatan dan memantau pelaksanaannya. Maka dari itu pada dasarnya restorative justice dikenal juga dengan penyelesaian perkara melalui mediasi (mediasi penal).

Mediasi penal dalam hukum pidana mempunyai tujuan mulia pada penyelesaian perkara pidana yang terjadi dalam masyarakat. Secara konseptual, dikatakan oleh Stefanie Trankle dalam Barda Nawawi Arief, mediasi penal yang dikembangkan itu bertolak dari ide dan prinsip kerja (working principles) sebagai berikut:

1. Penanganan konflik (Conflict Handling/Konfliktbearbeitung):

Tugas mediator adalah membuat para pihak melupakan kerangka hukum dan mendorong mereka terlibat dalam proses komunikasi. Hal ini didasarkan pada ide, bahwa kejahatan telah menimbulkan konflik interpersonal. Konflik itulah yang dituju oleh proses mediasi.

2. Berorientasi pada proses (Process Orientation/Prozessorientierung):

Mediasi penal lebih berorientasi pada kualitas proses daripada hasil, yaitu: menyadarkan pelaku tindak pidana akan kesalahannya, kebutuhankebutuhan konflik terpecahkan, ketenangan korban dari rasa takut, dsb. 
3. Proses informal (Informal Proceedings/Informalität): Mediasi penal merupakan suatu proses yang informal, tidak bersifat birokratis, menghindari prosedur hukum yang ketat.

4. Ada partisipasi aktif dan otonom para pihak (Active and autonomous participation/Parteiautonomie/Subjek tivierung): Para pihak (pelaku dan korban) tidak dilihat sebagai objek dari prosedur hukum pidana, tetapi lebih sebagai subjek yang mempunyai tanggung jawab pribadi dan kemampuan untuk berbuat. Mereka diharapkan berbuat atas kehendaknya sendiri. ${ }^{21}$

Permasalahan utama untuk memberlakukan atau mengimplementasikan pendekatan atau konsep keadilan restoratif (restorative justice) dalam sebuah sistem hukum pada umumnya dan pada sistem peradilan pidana pada khsusunya terletak pada mekanisme penyelesaian yang ditawarkan oleh pendekatan atau konsep keadilan restoratif (restorative justice) berbeda dengan mekanisme penyelesaian yang ditawarkan oleh sistem peradilan pidana yang ada saat ini sehingga masih sulit untuk diterima. Hal ini dikarenakan mekanisme yang ditawarkan oleh pendekatan atau konsep

21 Barda Nawawi Arief, Mediasi Penal Penyelesaian Perkara Di Luar Pengadilan, Pustaka Magister, Semarang, 2012, hlm. 4-5. keadilan restoratif (restorative justice) lebih mengedepankan konsep perdamaian, konsep "mediasi" dan konsep rekonsiliasi di mana pelaku, korban, aparat penegak hukum dan masyarakat luas berpartisipasi secara langsung dalam menyelesaikan perkara pidana tentunya berbanding terbalik atau bertentangan dengan sistem peradilan pidana tradisional yang sudah diberlakukan sejak lama dan berlaku hingga saat ini.

Hal ini dilatar belakangi oleh fokus perhatian dan pandangan atas suatu tindak pidana dan keadilan yang dicapai atas suatu penyelesaian perkara pidana. Pandangan terhadap arti dari suatu tindak pidana dan pemidanaan yang dianut dalam sistem peradilan pidana tradisional saat ini adalah "is a violation of the state, defined by lawbreaking and guilty" (pelanggaran negara didefinisikan sebagai pelanggaran hukum dan bersalah). Sementara keadilan dalam sistem peradilan pidana tradisional dipahami sebagai "terbuktinya dakwaan dan penjatuhan pidana kepada pelaku oleh Negara sebagai pemegang kedaulatan dalam menjatuhkan pidana. Otoritas demikian pada akhirnya justru berimbas pada kondisi tidak terwakilinya kepentingan korban dan masyarakat dalam sebuah sistem yang berkaitan satu dengan yang lain. 
Praktik-praktik penyelesaian masalah dengan pendekatan atau konsep keadilan restoratif (restorative justice) memang telah ada dalam kultur atau budaya bangsa Indonesia, sekalipun hal itu dilakukan oleh kalangan elit tertentu dari masyarakat. Braithwaite berkeyakinan dengan memberikan sedikit pelatihan maka tidak hanya kalangan elit saja yang dapat memfasilitasi praktikpraktik penyelesaiam masalah dengan pendekatan atau konsep keadilan restoratif namun lebih banyak orang, sekalipun demikian, upaya pendemokrasian praktikpraktik restoratif terhadap orang-orang Asia dapat berpotensi menimbulkan suatu kekeliruan.

\section{KESIMPULAN}

Restorative Justice (Keadilan Restoratif) atau dikenal dengan istlah "reparative justice" adalah suatu pendekatan keadilan yang memfokuskan kepada kebutuhan dari pada para korban, pelaku kejahatan, dan juga melibatkan peran serta masyarakat, dan tidak sematamata memenuhi ketentuan hukum atau semata-mata penjatuhan pidana. Dalam hal ini korban juga dilibatkan di dalam proses, sementara pelaku kejahatan juga didorong untuk mempertanggungjawabkan atas tindakannya, yaitu dengan memperbaiki kesalahan-kesalahan yang telah mereka perbuat dengan meminta maaf, mengembalikan uang telah dicuri, atau dengan melakukan pelayanan masyarakat. Restorative Justice bertujuan untuk memberdayakan para korban, pelaku, keluarga, dan masyarakat untuk memperbaiki suatu perbuatan melawan hukum dengan menggunakan kesadaran dan keinsyafan sebagai landasan untuk memperbaiki kehidupan bermasyarakat menjelaskan bahwa konsep Restorative Justice pada dasarnya sederhana. Restorative Justice merupakan teori keadilan yang menekan kan pada pemulihan kerugian yang disebabkan oleh perbuatan pidana.

Pendekatan Restorative justice memfokuskan kepada kebutuhan baik korban maupun pelaku kejahatan. Di samping itu, pendekatan Restorative Justice (Keadilan Restoratif) membantu para pelaku kejahatan untuk menghindari kejahatan lainnya pada masa yang akan datang.

\section{DAFTAR PUSTAKA}

Apong Herlina dkk, 2004, Perlindungan Terhadap Anak Yang Berhadapan Dengan Hukum, PT. Raja Grafindo Persada, Jakarta.

Dwidja Priyatno, 2007, Pemindanaan untuk Anak dalam Konsep Rancangan KUHP (dalam Kerangka Restorative Justice), Lembaga Advokasi Hak Anak 
(LAHA), Edisi VIII/Volume III, Bandung.

Rudi Rizky (ed), 2008, Refleksi Dinamika Hukum (Rangkaian Pemikiran dalam Dekade Terakhir), Perum Percetakan Negara Indonesia, Jakarta.

UNODC, 2006, Handbook on Restorative Justice Programmes. Criminal Justice Handbook Series, Vienna: UN New York.

John Braithwaite, 2002, Restorative Justice \& Responsive Regulation, England: Oxford University Press.

Nikmah Rosidah, 2014, Budaya Hukum Hakim Anak Di Indonesia, Pustaka Magister, Semarang.

Barda Nawawi Arief, 2008, Mediasi Penal Penyelesaian Perkara Diluar Pengadilan, Pustaka Magister, Semarang.

Eva Achjani Zulfa, 2009, Keadilan Restoratif, Jakarta:Badan Penerbit FH UI, Jakarta.

\section{Jurnal}

Setyo Utomo, Sistem Pemidanaan Dalam Hukum Pidana Yang Berbasis Restorative Justice, Mimbar Justitia Fakultas Hukum Universitas Suryakancana, Cianjur, Vol. 5 No. 01

\section{Makalah}

Lilik Mulyadi, "Penyelesaian Perkara Di Luar Pengadilan Melalui Dimensi Mediasi Penal (Penal Mediation) Dalam Sistem Peradilan Pidana.
Pengkajian Asas, Norma, Teori dan Praktek", Makalah ini dipresentasikan dalam rangka Penelitian untuk wilayah Pengadilan Tinggi Palangkaraya, Mataram, Jambi dan Semarang diselenggarakan Badan Penelitian dan Pengembangan dan Pendidikan dan Pelatihan Hukum dan Peradilan Mahkamah Agung RI (Badan Litbang Diklat Kumdil MARI) pada bulan April-Mei Tahun 2011 